\title{
Comparative Analysis of Managerial Ownership and Its Effect on Corporate Performance in Selected Asian and European Transition Economies
}

\author{
Darko Tipuric, Domagoj Hruska, Maja Darabos \\ University of Zagreb, Zagreb, Croatia
}

\begin{abstract}
This paper analyzes determinants and consequences of managerial ownership within ownership structures of the selected European and Asian transition countries. Focus of the analysis is the influence of the specific unification of ownership and control on corporate performance. Findings in the paper are based on research that produced empirical data for Croatia which is subsequently compared with evidence from other Asian and European transition countries facing the same issues. Consequently, transitional ownership structures, influenced by actual privatization process, like emergent corporate governance mechanisms, highly concentrated ownership and undeveloped markets for corporate control are also described. Research findings show that direct or indirect managerial ownership are important phenomena in transition countries, research has also shown that stable and concentrated managerial ownership have positive effects on firms' profitability in the observed transitional environments.
\end{abstract}

Keywords: transition, corporate governance, market for corporate control, ownership structure, managerial ownership

\section{Introduction}

The development of suitable mechanisms of corporate governance in transition countries differs from the same process in developed countries. One of the most notable differences is faulty legal framework and the lack of financial institutions. The legal system of transition economies has to adopt private ownership, financial reporting and bankruptcy laws. Although this kind of legislation is likely to exist in most of transition economies, its efficacy can differ from country to country. Transition economies of Europe and Asia differ significantly in their history and the current institutional environment but they also share some common traits. All of these countries have or have had a large number of state-owned corporations which needed to be restructured.

In this paper, we examine the relationship between shareholders and managers in transition economies with the focus on phenomena of managerial ownership. Firstly, we show literature survey on the influence of managerial ownership on corporate performance. Secondly, we offer results from empirical research on managerial ownership on the sample of biggest Croatian companies. And thirdly, we offer comparative analysis of the phenomena in different European and Asian countries.

Darko Tipuric, Ph.D., professor, Faculty of Economics and Business, University of Zagreb.

Domagoj Hruska, Ph.D., Faculty of Economics and Business, University of Zagreb.

Maja Darabos, MA, Faculty of Economics and Business, University of Zagreb. 


\section{Framework for Analysis of Managerial Ownership in Transition Countries}

In spite of the relevance of managerial ownership for corporate governance research, there is no empirical or theoretical consensus about the nature and consequences of managerial ownership.

Most research looks at the influence of managerial ownership on the performance of the company. Several important studies set the path for the research of that problem. Demsetz and Lehn study from 1985 calling for optimal ownership share determination to eliminate the influence of ownership on the company's performance. They suppose that companies constantly create new contracts because there are no costs of adapting to the owners' and managers' interests.

Morck, Shleifer and Vishny (1988) thought that managerial co-ownership should be more present, and in that case, companies would perform better. Their study is about the influence of managerial ownership and the Tobin's $q$ for 371 Fortune 500 companies in 1980. It was found that the Tobin's $q$ increases as the managerial ownership increases from $0 \%$ to $5 \%$. When managerial ownership increases from $5 \%$ to $25 \%$, Tobin's $q$ decreases but increases again after the share of managerial ownership grows past $25 \%$. The increase of Tobin's $q$ supports the effect of stimulus while the decrease of Tobin's $q$ supports the theory of managerial entrenchment.

McConnel and Servaes (1990) confirm the non-linear correlation, but in a different way from Morck et al. (1988). They found a positive correlation until the level of $40 \%-50 \%$ and a negative correlation on a level higher than that. The McConell and Servaes (1990) approve of the positive correlation between managerial ownership and firm performance, profitability increases as the share of managerial ownership increases. These studies mostly interpret the positive correlation between managerial ownership and firm performance at a low level of managerial ownership as a proof of aligned interests of principals and agents. The negative correlation at a high level of managerial ownership is interpreted as a proof managerial entrenchment, so that managers do not maximize the benefit for the company without being disciplined by the shareholders. Similarly, Short and Keasey (1999) have found that the interests of managers and owners align on low levels of management ownership and that managerial entrenchment appears at high levels of managerial ownership.

When it comes to managerial entrenchment, the argument is based on the negative correlation between managerial ownership and profitability, especially at high levels of managerial ownership. The higher the ownership share of managers, the harder it is for external owners to control the management. Taking into account the hypothesis of stimulus and entrenchment, the authors have found a non-linear correlation between managerial ownership and company performance (Mueller \& Spitz, 2001).

Managerial ownership in the interval from 0 to $5 \%$ implies a better company performance in most of the studies (Holderness, Kroszner, \& Sheehan, 1999; Kroszner \& Sheehan, 1999; Morck et al., 1988). There is opinion that managers do not have a tendency towards large quantities of stocks due to diversification of risk in their portfolio. From a manager's perspective, an optimal contract should take a manager's wish for diversification of specific components of corporate risk into account (Garvey \& Milbourn, 2003; Jin, 2002 according to Florackis, Kostakis, \& Ozkan, 2009). Core and Larcker (2002) claim that adopting plan of managerial ownership is a good strategy because it requires managers to own a minimal amount of shares which results in a better company performance.

Holderness et al. (1999) have made the most comprehensive comparison between managerial ownership 
and firm performance on 1,500 companies based on data from 1935 and 1995. They have found that managerial ownership amounted for $13 \%$ on average in 1935 and $21 \%$ in 1995 . The market value of the company decreased in cases of managerial ownership levels from $5 \%$ to $25 \%$ and increased in cases of managerial ownership levels above $25 \%$. They also claim that the increase of managerial ownership in the examined period of 60 years is not a result of the substitution of ownership with another means of solving the agency problem but that the increase of managerial ownership is a part of the general growth in the intensity of various alignments of interests in the modern corporation.

\section{Managerial Ownership in Croatia}

We analyze managerial ownership in sample consisting of 149 nonfinancial companies which is around $65 \%$ of such business entities in Croatia ${ }^{1}$. Financial companies are taken out of the analysis due to their specific accounting records. Hence data used in the research spreads in the period of nine years, from 2000 until the end of 2008.

Number of companies in the research differs from year to year because of availability of data for each case. Therefore our sample ranges from lowest number of 142 in 2001 to 149 companies in several following years. Such level of data deficiency should be comprehensible and it cannot significantly influence research results.

Level of managerial ownership can be examined from different points of view. One of the most usual approaches is to examine companies in which managers are also biggest shareholders. In such companies, managers undeniably have high influence, even if ownership concentration is low. In Croatia relatively small number of companies had managers as biggest shareholders. Percentage of such companies is relatively stable during the observed period, from $6.16 \%$ to $8.84 \%$ of the companies in the sample (see Table 1 ). Only 8 of the 149 companies in the survey managerial ownership was constant through all observed years.

Table 1

Number of Companies in Which Managers Were Biggest Shareholders

\begin{tabular}{lcl}
\hline Year & Number of companies & Percent of total number of companies \\
\hline 2000 & 7 & $6.25 \%$ \\
2001 & 9 & $7.04 \%$ \\
2002 & 10 & $7.69 \%$ \\
2003 & 11 & $7.48 \%$ \\
2004 & 11 & $7.48 \%$ \\
2005 & 13 & $8.84 \%$ \\
2006 & 11 & $7.48 \%$ \\
2007 & 9 & $6.16 \%$ \\
2008 & 9 & $6.21 \%$ \\
\hline
\end{tabular}

That information, however, does not tell us very much about the nature and level of control in the hands of managers/shareholders, nor does it say much about level of agency problem at such instances. More valuable information would give us insight into level of managerial ownership in respect to holdings of other shareholders.

\footnotetext{
${ }^{1}$ For investigation of importance of managerial ownership in Croatian practice of corporate governance we have used population of the biggest nonfinancial corporations in Croatia. According to Croatian capital market law all companies that had at least 100 shareholders and equity of 30 million kuna, had to disclose its performance records as well as other relevant information. The law has been changed from beginning of 2009 since the companies are not obliged to disclose information anymore.
} 
From that point of view, our research shows how at average $74.48 \%$ of the surveyed companies managers do not have any shares of the company they work in.

In some cases (8.42\%) managers have up to $5 \%$ of shares. Primary intention of those ownership levels is remuneration of top managers since it does not give them much of the controlling power. It is interesting to notice that in smaller number of cases (6.26\%) managers have between $5 \%$ and $20 \%$ of the company shares. Also, there are $5.51 \%$ of managers who hold more than $20 \%$ of shares in companies they work in and about the same number $(5.33 \%)$.

This analysis brings us to important question of corporate control and managerial ownership. We argue that in transitional corporate governance context managers who hold less than $20 \%$ of shares usually do not exercise at significant level of corporate control. Of course that is so in the situation where they are not shareholder with highest holdings, but that is rarely the case. Levels of ownership concentration in Croatia as well as in other transition countries give support to such assertion. Since in insider model of corporate governance (Europe and Japan) ownership concentration is higher than in outsider model (Anglo-Saxon), so in use of corporate control, we assume that managers need to have at least $20 \%$ of shares (see Table 2 ).

Table 2

Levels of Managerial Ownership in Croatian Companies

\begin{tabular}{lrrrrrrrrrr}
\hline Percent (\%) & \multicolumn{1}{c}{2000} & \multicolumn{1}{c}{2001} & 2002 & 2003 & 2004 & 2005 & 2006 & 2007 & 2008 \\
\hline 0 & 120 & 115 & 93 & 99 & 111 & 104 & 111 & 112 & 109 \\
$0.01-5$ & 11 & 12 & 19 & 17 & 10 & 14 & 10 & 9 & 8 & 12 \\
$5.01-20$ & 5 & 5 & 9 & 11 & 8 & 11 & 9 & 12 & 7 \\
$20.01-50$ & 7 & 7 & 13 & 11 & 8 & 6 & 7 & 7 & 6 \\
$50.01+$ & 1 & 3 & 9 & 9 & 10 & 12 & 10 & 6 & 9 \\
Total & 144 & 142 & 143 & 147 & 147 & 147 & 147 & 146 & 144 \\
\hline
\end{tabular}

Significantly, higher level of ownership concentration in transition countries in respect to ownership levels in developed economies points to the fact that higher level of managerial ownership is also required in pursuit of exercising significant level of corporate control. Therefore, in our analysis we are mostly interested in companies in which managers hold more than $20 \%$ of the company's shares, which is $10.48 \%$ of the companies in the sample.

However, our research of the link between managerial ownership and firm performance did not find any significant associations with number of accounting measures we used (net profit, EBIT, return on sales).

Even if companies from the sample do not show any significant relation between managerial ownership and corporate performance data offer us one more interesting insight - managerial levels in respect to industry in which company competes in.

Companies from the sample compete in several areas. Almost all surveyed companies come from one of the seven large sectors: agriculture, forestry and fishing; manufacturing; construction; trade; transport; tourism; technical, scientific and expert services. Most companies from the sample are from manufacturing sector (44\%) and tourism sector (23\%) while other areas comprise around $4 \%$ to $8 \%$ each.

Managerial ownership in Croatia, according to data from the research, significantly differs between industry sectors (see Table 3).

In sector of construction almost $80 \%$ of the companies have some levels of managerial ownership. In two 
other sectors: manufacturing and trade managerial ownership can be found in about $30 \%$ of companies from the sample. According to our research, tourism sector demonstrate lowest level of managerial ownership (12.75\%). These significant differences imply different evolutionary path of managerial ownership in different sectors which probably have its roots in dissimilar level of attractiveness and industrial enacted environments (Weick, 1995).

Table 3

Managerial Ownership in Different Industry Sectors

\begin{tabular}{llrrrrrrrrrrr}
\hline Industry sectors & $\begin{array}{l}\text { No. of } \\
\text { companies in } \\
\text { the sector }\end{array}$ & 2000 & 2001 & 2002 & 2003 & 2004 & 2005 & 2006 & 2007 & $\begin{array}{l}\text { 2008 } \\
\begin{array}{l}\text { Average } \\
\text { per sector } \\
(\%)\end{array}\end{array}$ \\
\hline $\begin{array}{l}\text { Agriculture, forestry } \\
\text { and fishing }\end{array}$ & 7 & 0 & 0 & 1 & 2 & 1 & 2 & 2 & 1 & 2 & 17.46 \\
Manufacturing & 65 & 15 & 15 & 23 & 25 & 21 & 24 & 19 & 19 & 18 & 30.60 \\
Construction & 6 & 3 & 3 & 6 & 5 & 5 & 5 & 6 & 5 & 5 & 79.63 \\
Trade & 12 & 4 & 4 & 7 & 6 & 3 & 2 & 2 & 2 & 4 & 31.48 \\
Transport & 11 & 0 & 1 & 3 & 2 & 1 & 2 & 3 & 3 & 2 & 17.17 \\
Tourism & 34 & 1 & 3 & 9 & 6 & 4 & 6 & 3 & 3 & 4 & 12.75 \\
Technical, scientific & 7 & 1 & 1 & 1 & 2 & 1 & 2 & 1 & 1 & 1 & 17.46 \\
and expert services & 6 & 0 & 0 & 0 & 0 & 0 & 0 & 0 & 0 & 0 & 0 \\
Other sectors & 6 & & & & & & & & & \\
\hline
\end{tabular}

\section{Firm Performance and Managerial Ownership-Empirical Evidence Across the World}

Research results of firm performance and managerial ownership in different corporate governance context show contradictory evidence. In the following part of the paper we offer comparative analysis of the research of managerial ownership. Firstly we examine situation in European transition countries namely in Poland, Czech Republic and Slovenia. After that, we compare determinants and consequences of managerial ownership in European transition countries with evidence from the selected Asian countries: China, Pakistan and Japan.

Due to the specificity of transition and the special functions of insider and managerial ownership, the effects of managerial ownership and firm performance are more complicated in transition countries. Empirical studies mostly record a negative correlation between managerial ownership and firm performance (Earle \& Estrin, 1997; Carlin et al., 1995; Frydman et al., 1999; Claessens \& Djankov, 1998).

Most of the research studying financial results of a company's performance show that managerial ownership increases as the performance results improve in the interval of $0 \%$ to $5 \%$, while the evidence of other intervals are not significant enough to identify a correlation. However, authors mostly agree upon the fact that managerial ownership higher than $50 \%$ makes it impossible to lay off managers. That results in problems concerning managerial entrenchment.

\section{Selected European Countries}

Privatization in Central and Eastern Europe provides a good opportunity to study the change in corporate governance in newly privatized firms. One of the explicit motivations for rapid privatization in these countries was the need to improve corporate governance of the previously state-owned enterprises.

For the last 20 years, Polish enterprises have been a playground for deep and wide institutional changes including, first of all, ownership and control. The background of these changes as well as their outcomes has varied significantly over time. Both politically forced re-arrangement of control without ownership changes and 
market driven reforms affecting ownership (privatization) and (for some enterprises to a lesser extent) control rescheduling could be observed within this period of time. In Poland, especially in smaller firms, managerial ownership is quite large. Frequently, managers are also the company founders and first or second largest block-holder.

The first evidence on ownership structure is reported by Belka et al. (1995). They found that in 23 out of 200 analyzed enterprises ownership was concentrated. The largest shareholder usually held about $50 \%$ of shares with a tendency towards $70 \%-85 \%$. The ownership was additionally limited to a very narrow circle. In a few cases, ownership was shared by two partners (50/50 or 49/51). Eight out of 23 corporations were in the hands of senior managers and/or employees, 10 were controlled by private individuals and 10 by foreign or joint venture entities. The position of managers and employees in privatized corporations was further investigated. In 22 out of 40 cases, managers and other employees together held a dominant position among shareholders. Managers owned on average $21.6 \%$ of shares compared to $48.8 \%$ in employees' hands. Domestic private banks (average shareholding of 3\%), investment funds, individuals and firms were reported among minority shareholders. Belka et al. (1995) concluded that the position of managers in governance of privatized enterprises was very strong.

In an extensive study, Kozarzewski (1999) documented that employee shareholdings declined over time while managers and outsiders leveraged their positions. In about 35 cases, it was noted that managers held blocks of shares ranging from $5 \%$ up to $93 \%$ with an average block of $28.5 \%$. Moreover, in 20 corporations the blocks owned by managers were simultaneously the largest ones and in 10 cases the second largest. In the majority of these cases managers belonged to a narrow group of founders.

A lot of the empirical work on the relation between ownership structure and corporate performance has had difficulty in controlling for the possible feedback of firm characteristics to ownership, especially since it has focused mainly on market economies with low transaction costs in changing ownership. The design of the Czech privatization program precluded the adjustment of ownership to firm characteristics. In particular, the decision to change ownership was taken by the state, while the rules of the bidding process prevented participating agents from obtaining optimal ownership structure.

Consequently, we can study the link between concentrated ownership and firm performance following voucher privatization. The Czech voucher scheme prevented insiders from acquiring large ownership stakes, as few direct sales of assets took place before the voucher privatization. The Czech voucher was not transferable so that the accumulation of an individual stake from the percentage of shares allocated to voucher privatization was impossible.

Claessens and Djankov (1999) have related ownership concentration on two corporate performance parameters for a cross section of Czech firms over the period 1992 through 1997. The average stake in firms owned by managers was similar through this period, and it was around 35\%. In particular, they have tested whether firms with more concentrated ownership have experienced larger positive changes in profitability and labor productivity. Controlling for some firm-specific variables, they founded that both profitability and productivity changes are positively related to ownership concentration. A $10 \%$ increase in concentration leads to a $2 \%$ increase in short-term labor productivity and a $3 \%$ increase in short-term profitability.

Slovenia's privatization brought about two large groups of owners: inside owners (employees, including managers, former employees and their relatives) and outside owners (Pension and Restitution Funds, Privatization Investment Funds). Within the group of insiders, managers ended up holding only minority stakes 
(3.86\%) with the support of the employees as the main mechanism for ensuring their discretionary power and fighting the influence of outsiders (Prasnikar \& Gregoric, 2002; Gregoric, 2003).

Due to the shrinking employee ownership and hence the reduction of the "hidden" support for managers in the post-privatization period, Slovenian managers have started strengthening their power by expanding their ownership stakes. These increases are the most prominent in non-listed firms in which the transfer of ownership involves relatively low prices and mostly remains undisclosed to the public. Further, the remaining dissatisfaction of managers (at the end of 2002, the optimal or desired ownership stake of the average Slovenian manager exceeded their actual ownership stake by $10.8 \%$ ) clearly indicates that the trend of rising managerial ownership in Slovenian firms will also continue in the future.

The empirical analysis (Simoneti \& Gregoric, 2004) of managerial ownership and firm performance in the Slovenian post-privatization period does not provide any support for the conclusion that managerial ownership positively influences the long-term economic efficiency of Slovenian firms (measured as total factor productivity growth). The first empirical results indicate that it can be expected that managerial ownership will have a positive effect (and hence create incentives) on firm financial performance, in particular in unlisted firms and in those firms whose managers hold more than $10 \%$ of the capital. On the other hand, the nontransparent increase seen in managerial ownership in unlisted firms fortunately seems to have no negative effect on the economic efficiency and hence the long-term performance of Slovenian firms.

Although ideological factors may be relevant to the analysis of privatization in post-communist countries, it is difficult to extend the argument to the rest of the developing world. The political and economic elites in Asia, for instance, have not experienced massive societal demands for a new ownership structure as happened in most of Eastern Europe and Russia (Whitehead, 2000). Nor does privatization in Asia seem to be originated from a project designed by political elite that differed from the previous statist elite in its ideological orientation.

\section{Selected Asian Countries}

There are very few studies which have examined Chinese firms for the managerial ownership performance relationship. One apparent reason is that under the unique regulatory environment in China, managerial ownership in listed companies is usually very low. For a sample of 5,284 publicly traded Chinese firms, Wei et al. (2005) report an average stock holding of merely $0.015 \%$ by senior managers and directors. From this evidence we can conclude that managerial ownership in listed companies is mostly negligible, and this is due to institutional and policy constraints in China. On the other hand, managerial equity holdings can be substantive in small and typically non-listed companies.

$\mathrm{Hu}$ and Zhou (2008) provided the first evidence from China for the effect of managerial ownership on firm performance by examining a sample of non-listed Chinese firms. In matching-sample comparisons, they found that firms of significant managerial ownership outperform firms whose managers do not own equity shares. Their further results indicate the relation between firm performance and managerial ownership is nonlinear, and the inflection point at which the relation turns negative occurs at ownership above $50 \%$. They also founded that percentage of firms with managerial ownership is very small (5.5\%) as compared to typical situations in a developed market. Furthermore, they also came to conclusion that ownership distribution in China is highly concentrated and that the average managerial ownership of all firms in their sample with managerial ownership 
was as high as $70 \%$ (among which, only four firms' managerial ownership was less than $10 \%$ ). This observation, together with the fact that a small number of firms had managerial ownership, further suggests that managerial ownership in China was not an equilibrium outcome of incentive contracting but was constrained by government's polices and managers' personal wealth.

Most of the empirical studies about the relationship between managerial ownership and firm performance has covered the developed economies and there is little work done on the emerging economies, moreover, very little work has been done on emerging economy of Pakistan. It is in fact that in last few years, the low interest rate environment and investor friendly policies of the government of Pakistan coupled with positive geopolitical developments have paved the way for the macroeconomic conditions conducive for the development of the equity and money markets of the country. The increased investor's confidence along with the improvements in the corporate earnings has contributed to the impressive performance of the equity markets as compared to all other South East Asian economies.

In Pakistan, majority of the shareholdings are with board of directors, company executives and their spouses. In Pakistan, most of the businesses are laying with few big businessmen families. Family firms are a fundamental and intrinsic feature of the Pakistani economy. Approximately $80 \%$ of all listed companies on the Karachi Stock Exchange have family involvement or are indirectly affiliated to a large business family (Zaidi, 2005). These family firms were established traders in different parts of United India, and it was a historical accident that gave them opportunity to establish themselves in new land of Pakistan. Post privatization era in Pakistan also brought a new class of industrial and family businesses. Due to this fact, there is a lot of cross ownership in family firms and it has increased the ratio of insider ownership across the whole economy of Pakistan.

Choudhary and Talat (2008) showed that managerial ownership in Pakistan is higher than average managerial ownership stake of all board members in other countries such as Malaysia, USA and UK. Their research also found that average managerial ownership in Pakistan is $53.22 \%$, and it has proved that there is strong positive relationship between managerial ownership and firm performance in Pakistan. The above results have provided the positive indications for Pakistani corporate sector to solve the agency problem through stock options for their employees.

Ownership is highly concentrated in Japan, with financial institutions by far the most important large shareholders. Ownership concentration in independent Japanese firms is positively related to the returns from exerting greater control over management. This is not the case in firms that are members of corporate groups (keiretsu). Japan differs from the U.S. because the legal and regulatory environment of Japanese financial institutions permits them to be what Jensen (1989) has termed "active investors" to a much greater extent in corporations. Within Japan there exist differences between firms that are affiliated with keiretsu groups and unaffiliated, independent firms concerning institutional arrangements with suppliers, customers, and financiers. Japanese industrial organization is characterized by groups of enterprises (keiretsu) composed of firms based in different industries, but bound by ties of fractional ownership, and reliant on a large commercial bank as the major lender.

Management shareholding in Japanese companies may be rather less important. Individuals ranking among the top five shareholders of the firm hold on average 3\% of the firm's outstanding shares. Even if we assume these individuals are all managers, this still appears low. Kaplan (1992) reported that in a sample of large 
Japanese firms, only $12.2 \%$ of Japanese presidents held more than $0.5 \%$ of their company's stock in 1981 .

For example, the market for corporate control in Japan appears much less active (at least among large firms) than in the United States. In addition, if management shareholding in Japanese firms is indeed rather less important than it is in the U.S., then the structure of management compensation in Japanese firms by itself might plausibly give managers less incentive than their U.S. counterparts to follow value-maximizing policies.

There is little evidence of any relationship between ownership concentration and profitability for keiretsu or independent firms. We can conclude that, given there is no significant relationship between profitability and ownership concentration in keiretsu firms, large shareholders of keiretsu firms may have means to monitor and control management other than through their role as a shareholder (Prowse, 1992).

In addition, Teshima (2008) have constructed theoretical model which suggests that as managerial ownership increases, earnings management decreases for both high and low levels of managerial ownership, while it increases for intermediate levels of managerial ownership if the sensitivity of the probability of managerial dismissal to the corporate performance is high enough and/or the manager's private benefit derived from managerial position is high enough. In a sample of Japanese firms, we find a significant nonmonotonic relationship between managerial ownership and discretionary accruals.

\section{Conclusions}

Improving corporate governance practice in transition countries represents important research area. According to Stiglitz, the deficiency of corporate governance is one of the main reasons because which shareholders of private companies in transition countries have considered investments in development less profitable than disinvestment of privatized companies (Stiglitz, 1999). Economic growth of transition countries was lower than expected in the beginning of the transition process, mostly due to the fact that privatization did not bring significant changes in the efficiency of corporations (Gregoric, Prasnikar, \& Ribnikar, 2000).

By elaborating determinants and consequences of managerial ownership in transition countries, this paper enlightens broader area of corporate governance systems and its mechanisms. According to agency theory behavior of managers can potentially be harmful for the shareholders who hire them. In their work from 1976, Jensen and Meckling apply the agency theory into the modern corporation and shape agency costs (Jensen \& Meckling, 1976). That way they re-confirm the historical idea that goes all the way to Adam Smith-if the ownership and control is not embodied in one person, there is a possibility of conflict of interests between the manager and the owner (Smith, 1994; Smith, 1776). Managerial ownership is a way of combining roles of managers and owners in that way represent important research phenomena.

In spite of the importance of managerial ownership for researchers in the area of corporate governance, there is no empirical or theoretical consensus about the influence of managerial ownership on company performance. Our research on the sample of Croatian companies confirms that thesis.

While our research shows little evidence of any relationship between managerial ownership and company performance, it opens lot of interesting questions about the phenomena. Those questions lead us to the conclusion that measuring company performance in respect to managerial ownership should be done with qualitative metrological tools which would allow higher level of appreciation of contextual factors. 


\section{References}

Barca, F., \& Becht, M. (2001). The control of corporate Europe. Oxford University Press.

Becht, M., \& Röell, A. (1999). Blockholdings in Europe: An international comparison. European Economic Review, 43, $1049-1056$.

Belka, M., Estrin, S., Schaffer, M. E., \& Singh, I. J. (1995). Enterprise adjustment in Poland: Evidence from a survey of 200 private, privatized and state owned firms. Centre For Economic Performance, Discussion paper No. 233.

Berglöf, E., \& Thadden, E. L. (1999). The changing corporate governance Paradigm: Implications for transition and developing countries. Center for Advanced Study in the Behavioral Sciences, Stanford, California, 19.

Bornstein, M. (2001). Post-privatization enterprise restructuring. Post-Communist Economies, 13(2), 189-203.

Chen, H., Hexter, J. L., \& Hu, Y. (1993). Management ownership and corporate value. Managerial and Decisions Economics, 14(4), 335-346.

Chen, M. Y. (2005). Group affiliation, identity of managers, and the relation between managerial ownership and performance, International Review of Financial Analysis, 14, 533-558.

Choudhary, S., \& Talat, A. (2008). Insider ownership and corporate performance: Evidence from an emerging economy, Proceedings of ASBBS, 15(1), 957-967.

Chung, K. H., \& Pruitt, S. W. (1994). A simple approximation of Tobin's Q. Financial Management, 23, 70-74.

Claessens, S., \& Djankov, S. (1999). Ownership concentration and corporate performance in the Czech Republic. Journal of Comparative Economics, 27, 498-513.

Cornelli, F., Portes, R., \& Schaffer, M. E. (1996). The capital structure of firms in Central and Eastern Europe. CEPR discussion paper No. 1392.

Darrough, M. N., Pourjalali, H., \& Saudagaran, S. (1998). Earnings management in Japanese companies. International Journal of Accounting, 33, 313-334.

Davies, J. R., Hillier, D., \& McColgan, P. T. (2005). Ownership structure, managerial behavior and corporate value. Journal of Corporate Finance, 11, 645-660.

Demsetz, H. (1983). The structure of ownership and the theory of the firm. Journal of Law and Economics, 26, 375-390.

Demsetz, H., \& Lehn, K. (1985). The structure of ownership: Causes and consequences. Journal of Political Economy, 93, 1155-1177.

Demsetz, H., \& Villalonga, B. (2001). Ownership structure and corporate performance. Journal of Corporate Finance, 7, $209-233$.

Denis, D. J., \& Sarin, A. (1999). Ownership and board structures in publicly traded corporations. Journal of Financial Economics, 52, 187-223.

Dzierżanowski, M., \& Tamowicz, P. (2004). Ownership and control of polish corporations. Corporate Ownership \& Control, 1, 20-30.

Fama, E. F. (1980). Agency problems and the theory of the firm. Journal of Political Economy, 88, 288-307.

Fama, E. F., \& Jensen, M. (1983). Separation of Ownership and Control. Journal of Law and Economics, 26, 301-349.

Franks, J., Mayer, C., \& Renneboog, L. (2001). Who disciplines management in poorly performing companies? Journal of Financial Intermediation, 10, 209-248.

Frydman, R., Gray, C., Hessel, M., \& Rapaczynski, A. (1999). When does privatization work? The impact of private ownership on corporate performance in transition economies. Quarterly Journal of Economics, 114(4), 1153-1191.

Gardawski, J. (2000). Forming of owner groups in privatized enterprises. In M. Jarosz (Ed.), Ten years of direct privatization, ISP PAN.

Gregoric, A., Prasnikar, J., \& Ribnikar, I. (2000). Corporate governance in transitional economies: The case of Slovenia. Economic and Business Review, 2(3), 183-207.

Grosfeld, I., \& Hashi, I. (2007). Changes in ownership concentration in mass privatised firms: Evidence from Poland and the Czech Republic. Journal compilation, 15(4), 520-534.

Grosfeld, I., \& Nivet, J. F. (1997). Firm's heterogeneity in transition: Evidence from a Polish, panel data set, William Davidson Institute working paper No.47.

Gupta, N., Ham, J. C., \& Svejnar, J. (2000). Priorities and sequencing in privatization: Theory and evidence from the Czech Republic. William Davidson Institute working paper No. 323.

Hashi, I. (2000). The Polish national investment fund program: Mass privatization with a difference? Comparative Economic Studies, 42, 87-134. 
Himmelberg, C. P., Hubbard, R. G., \& Palia, D. (1999). Understanding the determinants of managerial ownership and the link between ownership and performance. Journal of Financial Economics, 53, 353-384.

Hu, Y., \& Izumida, S. (2008). The relationship between ownership and performance: A review of theory and evidence. International Business Research, 1(4), 72-82.

$\mathrm{Hu}, \mathrm{Y} .$, \& Zhou, X. (2008). The performance effect of managerial ownership: Evidence from China. Journal of Banking \& Finance, 32, 2099-2110.

Jensen, M. C., \& Meckling, W. H. (1976). Theory of the firm: managerial behavior, agency costs, and ownership structure. Journal of Financial Economics, 3, 305-360.

Kočenda, E. (1999). Residual state property in the Czech Republic. Eastern European Economics, 37(5), 6-35.

Kočenda, E., \& Svejnar, J. (2003). Ownership and firm performance after large-scale privatization. Fifth International Conference on "Enterprise in Transition", 2194-2222.

Kozarzewski, P. (2001). Corporate governance restructuring in the course of privatization in Poland, enterprise in transition, University of Split, Faculty of Economics, Split-Hvar, 2001, 2053-2074.

Kryštof, M. (2005) Corporate governance and ownership concentration in the Czech Republic, Univerzita Karlova v Praze.

Lichtenberg, F. R., \& Pushner, G. M. (1994). Ownership structure and corporate performance in Japan. Japan and the World Economy, 6, 239-261.

Maury, C. B., \& Pajuste, A. (2002). Controlling shareholders, agency problems, and dividend. Policy in Finland, LTA, 1(2).

Mejstrik, M. (Ed.). (1997). The privatization process in East-Central Europe: Evolutionary process of Czech Privatization. Economics of Transition, 5(2), 289-304.

Morck, R., Shleifer, A., \& Vishny, R. W. (1988). Management ownership and market valuation: An empirical analysis. Journal of Financial Economics, 20, 293-315.

Pajuste, A., \& Olsson, M. (2001). Ownership concentration: The case of the Baltic States, Konferencija corporate governance and disclosure in the accession process, CEPR/University of Ljubljana, Portorož.

Prowse, S. D. (1992). The structure of corporate ownership in Japan. The Journal of Finance, 47(3), 1121-1140.

Pučko, D. (2005). Corporate governance in European transition economies: Emerging models. Management, 10, 1-21.

Shleifer, A., \& Vishny, R. (1986). Large shareholders and corporate control. Journal of Political Economy, 94, 461-488.

Shuto, A. (2007). Executive compensation and earnings management: Empirical evidence from Japan. Journal of International Accounting, Auditing and Taxation, 16, 1-26.

Simoneti i Gregoric. (2004). Managerial ownership and corporate performance in Slovenian post-privatization period. The European Journal of Comparative Economics, 1(2), 217-241.

Smith, S., Cin, C., \& Vodopivec, M. (1997). Privatization incidence, ownership forms, and firm performance: Evidence from Slovenia. Journal of Comparative Economics, 25, 158-179.

Stiglitz, E., \& Joseph. (1999). Quis custodiet ipsos custodes? Corporate governance failures in the transition, Annual bank conference on development economics-Europe, Paris, 7.

Svejnar, J., \& Singer, M. (1994). Using vouchers to privatize an economy: The Czech and Slovak case. Economics of Transition, 2, 43-64.

Teshima, N., \& Shuto, A. (2008). Managerial ownership and earnings management: Theory and empirical evidence from Japan. Journal of International Financial Management and Accounting, 19(2), 107-132.

Weick, E. K. (1995). Sensemaking in organizations. Thousand Oaks: Sage Publications.

$\mathrm{Xu}$, X., \& Wang, Y. (1999). Ownership structure, corporate governance in Chinese stock companies. China Economic Review, 10, $75-98$.

Zhou, X. (2001). Understanding the determinants of managerial ownership and the link between ownership and performance: Comment. Journal of Financial Economics, 62, 559-571. 